OPEN ACCESS

Edited by:

Eduardo Luís Cupertino Ballester, Federal University of Paraná, Brazil

Reviewed by:

Sean Liao,

South China Normal University, China José María Maria Monserrat, Fundação Universidade Federal do

Rio Grande, Brazil

Carine De Freitas Souza Universidade Federal de Santa Maria,

Brazil

*Correspondence: Jixing Zou zoujixing@scau.edu.cn Lanfen Fan

fanlanfen@scau.edu.cn

Specialty section: This article was submitted to

Aquatic Physiology,

a section of the journal

Frontiers in Physiology

Received: 26 January 2019 Accepted: 24 July 2019

Published: 13 August 2019

Citation:

Wang Z, Qu Y, Yan M, Li J, Zou J and

Fan L (2019) Physiological Responses of Pacific White Shrimp Litopenaeus vannamei to Temperature Fluctuation in Low-Salinity Water.

Front. Physiol. 10:1025. doi: 10.3389/fphys.2019.01025

\section{Physiological Responses of Pacific White Shrimp Litopenaeus vannamei to Temperature Fluctuation in Low-Salinity Water}

\author{
Zhenlu Wang ${ }^{1,2}$, Yuexin $\mathrm{Qu}^{1,2}$, Muting Yan ${ }^{1,2}$, Junyi $\mathrm{Li}^{1,2}$, Jixing Zou ${ }^{1,2 \star}$ and Lanfen Fan ${ }^{1,2 \star}$ \\ ${ }^{1}$ Department of Aquaculture, College of Marine Sciences, South China Agricultural University, Guangzhou, China, ${ }^{2} J o i n t$ \\ Laboratory of Guangdong Province and Hong Kong Region on Marine Bioresource Conservation and Exploitation, South \\ China Agricultural University, Guangzhou, China
}

Temperature is a significant environmental factor in aquaculture. To investigate the physiological responses during temperature fluctuation $\left(28 \sim 13^{\circ} \mathrm{C}\right)$, experimental shrimps (Litopenaeus vannamei) were treated with gradual cooling from acclimation temperature $\left(\mathrm{AT}, 28^{\circ} \mathrm{C}\right.$ ) to $13^{\circ} \mathrm{C}$ with a cooling rate of $7.5^{\circ} \mathrm{C} /$ day and rose back to $28^{\circ} \mathrm{C}$ at the same rate after $13^{\circ} \mathrm{C}$ for $24 \mathrm{~h}$. Hepatopancreas histological changes, plasma metabolites concentrations, relative mRNA expression of unfolded protein response (UPR) pathway and apoptosis in hepatopancreas and hemocyte were investigated. The results showed that with the decline of temperature, the number and volume of the secretory cells in hepatopancreas increased significantly, the tubule lumen appeared dilatated, and the epithelial cell layer became thinner. The contents of glucose (Glu) significantly decreased to the minimum value of $13^{\circ} \mathrm{C}$ for $24 \mathrm{~h}$. The contents of triglyceride (TG), total cholesterol (TC), and total protein (TP) increased and reached the peak of $13^{\circ} \mathrm{C}$ for $24 \mathrm{~h}$. Alkaline phosphatase (ALP) and alanine aminotransferase (ALT) activities in plasma reached the lowest and highest value in $13^{\circ} \mathrm{C}$, respectively. The expressions of all genes related to UPR and apoptosis in the hepatopancreas and hemocytes were significantly changed during the cooling process and reached the highest level of 13 and $13^{\circ} \mathrm{C}$ for $24 \mathrm{~h}$, respectively. During re-warming stage, the histopathological symptoms got remission and each of the plasma metabolite concentrations and gene expressions returned to AT levels. These results revealed that pacific white shrimp can adapt to a certain level of temperature fluctuation by self-regulation.

Keywords: Litopenaeus vannamei, temperature, endoplasmic reticulum stress, apoptosis, self-regulation

\section{INTRODUCTION}

The pacific white shrimp Litopenaeus vannamei, with a wide range of salt-tolerance, rapid growth, and other characteristics suitable for intensive aquaculture, has become one of the most important aquaculture shrimps in the world. However, a variety of environmental stimuli affect the growth of shrimp, such as changes in pH (Han et al., 2018a), salinity (Li et al., 2008; 
Wang et al., 2016), dissolved oxygen (DO) (Han et al., 2018b), temperature (Madeira et al., 2015), and pollutants like nitrite, ammonia, and sulfide (Duan et al., 2018b).

Since the start of global climate change, various extreme climates have happened frequently. Previous studies have indicated that many extreme weather events which were associated with drastic temperature fluctuation can directly affect the growth, physiological performance, and survival of animals (He et al., 2018; Zhang et al., 2019). It has been studied that temperature changes may lead to growth arrest, stoppage of feeding, and swimming or even death in $13^{\circ} \mathrm{C}$ (Fan et al., 2013; Huang et al., 2017; Xu et al., 2018). Our previous study has indicated that glucose-regulated protein $78 \mathrm{kDa}$ (GRP78) was significantly up-regulated in the hepatopancreas of L. vannamei under $13^{\circ} \mathrm{C}$ for $24 \mathrm{~h}$ cold-stress (Fan et al., 2016). GRP78, also known as immunoglobulin-binding protein (BIP), is a central regulator of endoplasmic reticulum stress (ERS) and regulated the process of unfolded protein response (UPR) and apoptosis (Dejean et al., 2006; Nakka et al., 2010). At present, studies on ERS are mainly focused on mammals and the UPR pathway (Cao and Kaufman, 2012).

UPR is a self-protective mechanism which can promote cell survival in response to ERS. It includes three classical signaling pathways: the activating transcription factor 6 (ATF6) pathway, the inositol-requiring enzyme-1-X-box binding protein 1 (IRE1-XBP1) pathway, and the protein kinase RNA (PKR)like ER kinase-eIF2 $\alpha$ (PERK-eIF2 $\alpha$ ) pathway (Mori, 2009; Costa et al., 2011). In addition, apoptosis signals will be generated if stress is prolonged for protecting the organism by eliminating the damaged cells. Apoptosis signal-regulated kinase 1 (ASK1) is essential for the continuous activation of c-Jun NH2-terminal kinases (JNK) and induces cell apoptosis (Tobiume et al., 2001). Cysteine-containing aspartate-specific proteases (caspases) are a family of proteases that perform apoptosis in animals. Apoptosis mediated by ERS triggers a specific cascade of caspase 12, 9, and 3 , and the activation of caspase 3 (CASP3) indicates that apoptosis has entered an irreversible stage (Morishima et al., 2002). In invertebrates, UPR is widely recognized as the key to ER stress response (Chen and He, 2019). However, studies of the UPR signaling pathway and apoptosis in L. vannamei mainly focused on the immune function, especially in response to WSSV infection (Chen et al., 2012; Wang et al., 2013; Xu et al., 2014; Yuan et al., 2016, 2017, 2018). UPR in response to temperature fluctuation has not been reported.

Additionally, it has been identified that hepatopancreas histology could be used to monitor the impact of a stressed environment, showing ultrastructural alterations at the early stage of stress (Collins, 2010). Environmental changes like $\mathrm{pH}$ stress can cause change or damaged of hepatopancreas cells (Tao et al., 2016). However, it is still not clear about the change of hepatopancreas histology during temperature fluctuation process.

In the present study, based on the statistics of weather conditions from the winter (November, December and January) in Guangdong from 2017 to 2018 (China Meteorological Administration, www.cma.gov.cn), we found that the average daily temperature difference of winter in Guangdong was $7.52^{\circ} \mathrm{C}$.
The annual cold wave causes huge economic losses to the L. vannamei breeding industry in China. However, little was known about the responses of the shrimp during the process of temperature gradual cooling and warming. Thus, we investigated (1) histological section of the hepatopancreas, (2) metabolite concentrations of plasma, and (3) UPR gene and cell apoptosis gene expressions of hepatopancreas and hemocyte in $L$. vannamei during temperature fluctuations. These results could provide valuable reference to analyze the adaptation mechanism of the shrimp in response to temperature fluctuation.

\section{MATERIALS AND METHODS}

\section{Experimental Shrimp and Culture Conditions}

The experimental shrimps, with an average weight of $5.4 \pm 0.7 \mathrm{~g}$, were obtained from a commercial farm in Panyu (Guangdong, China). The shrimps were immediately transported to the lab and acclimated in $500 \mathrm{~L}$ filtered, aerated (oxygen pump, HAP-120, HAILEA, Guangdong, China) seawater tanks (Guanzhong, K500 L, Jiangsu, China) at least 4 days before experiments. During the acclimation stage, the water salinity and temperature in tanks were consistent with that of the culture ponds (salinity 5\%, $\mathrm{pH} 8.3 \pm 0.1$ and temperature $28 \pm 1^{\circ} \mathrm{C}$ ). Commercial shrimp feeds (Haida Group Feed, Jieyang, China) were given two times per day (5\% of shrimp body weight per time).

\section{Treatment}

Sixty-three healthy shrimps were randomly divided into three replicate tanks. They were placed in an artificial climate incubator (Laifu, Ningbo, China), and the water temperature was decreased from acclimation temperature (AT, $28^{\circ} \mathrm{C}$ ) to $13^{\circ} \mathrm{C}$ with a cooling rate of $7.5^{\circ} \mathrm{C} /$ day $\left(2.5^{\circ} \mathrm{C} / 8 \mathrm{~h}\right)$. After $13^{\circ} \mathrm{C}$ for $24 \mathrm{~h}$, the water temperature rose back to $28^{\circ} \mathrm{C}$ at the same rate.

\section{Sample Collection Tissue Slice}

At each temperature point $\left[28,23,18,13\right.$, and $13^{\circ} \mathrm{C}$ for $24 \mathrm{~h}$ during cooling process, 18 and $28^{\circ} \mathrm{C}$ during return process $\left(\mathrm{r} 18\right.$ and $\left.\left.\mathrm{r} 28^{\circ} \mathrm{C}\right)\right]$, the whole hepatopancreas of one shrimp from each tank were dissected from the cephalothoraxes and fixed with $4 \%$ paraformaldehyde (Biosharp, China) for tissue fixation and then stored in $4^{\circ} \mathrm{C}$ for paraffin sections by Servicebio (Wuhan, China).

\section{Plasma and Gene Expression Analysis}

Hemolymph was extracted from the ventral sinus of shrimp at each temperature point as same as tissue slice, using a $1 \mathrm{ml}$ sterile syringe containing an equal volume of ice-cold anticoagulant solution $(27 \mathrm{mM}$ trisodium citrate, $385 \mathrm{mM}$ sodium chloride, $115 \mathrm{mM}$ glucose, $\mathrm{pH}$ 7.5). Hemolymph of two shrimps from each tank was mixed as one sample, three repeats. After being centrifuged at $3000 \mathrm{rpm}$ (844g) for $10 \mathrm{~min}$ 
in $4^{\circ} \mathrm{C}$, the supernatant fluid was immediately stored in $-80^{\circ} \mathrm{C}$ for analysis of plasma metabolite concentrations. The pelleted hemocytes were collected, instantly frozen in liquid nitrogen and then stored at $-80^{\circ} \mathrm{C}$ for analysis of gene expression ( $\mathrm{Xu}$ et al., 2018). After hemolymph sampling, hepatopancreases were dissected, frozen in liquid nitrogen, and stored in $-80^{\circ} \mathrm{C}$ for gene expression analysis.

\section{RNA Extraction and cDNA Synthesis}

Total RNA was extracted from hemocytes and hepatopancreases using RNAiso Plus reagent (TaKaRa, Japan) following the manufacturer's protocol. RNA quality was assessed by electrophoresis on $1.0 \%$ agarose gel, and concentration was tested by mySPEC (VWR, USA). Total RNA was purified, and first-strand cDNA was synthesized using ReverTra Ace ${ }^{\circledR}$ qPCR RT Master Mix with gDNA Remover (TOYOBO, Shanghai) according to the manufacturer's instructions.

\section{Real-Time Quantitative PCR}

The SYBR Green real-time Polymerase Chain Reaction (PCR) assays were carried out on a CFX Connect ${ }^{\mathrm{TM}}$ Real-Time System (Bio-Rad) using THUNDERBIRD ${ }^{\circledR} \quad$ SYBR $^{\circledR} \quad$ qPCR Mix (TOYOBO). Previous studies showed that the expressions of $\beta$-actin were constant after environmental stimuli such as ammonia (Duan et al., 2018a), dissolved oxygen (Han et al., 2018b), and pH stress (Han et al., 2018a). Therefore, we used $\beta$-actin as the housekeeping gene, and specific primer sequences were designed based on the coding sequence of the target genes using Primer Premier 6.0 software (Table 1). The realtime PCR program was $95^{\circ} \mathrm{C}$ for $1 \mathrm{~min}$, followed by 40 cycles of $95^{\circ} \mathrm{C}$ for $15 \mathrm{~s}, 60^{\circ} \mathrm{C}$ for $15 \mathrm{~s}$, and $72^{\circ} \mathrm{C}$ for $45 \mathrm{~s}$, followed by 1 step of $95^{\circ} \mathrm{C}$ for $10 \mathrm{~s}$. Melting curves were obtained by increasing the temperature from 65 to $95^{\circ} \mathrm{C}\left(0.5^{\circ} \mathrm{C} / \mathrm{s}\right)$ to denature the double-stranded DNA. The relative mRNA expressions were calculated by the comparative $\mathrm{Ct}$ method $\left(2^{-\Delta \Delta \mathrm{Ct}}\right)$.

\section{Statistical Analyses}

All the data were presented as mean \pm SD of triplicates. Data were statistically analyzed by SPSS 19.0 with one-way ANOVA and Tukey test. $p<0.05$ was significant difference.

\section{RESULTS}

\section{Hepatopancreas Histological Analysis}

According to the results of hepatopancreas with HE staining, the hepatocytes in $28^{\circ} \mathrm{C}$ exhibited the well-organized tubules. With the decrease of temperature, stellate tubule lumen appeared dilatation, and some vacuoles appeared and ruptured to make the epithelial cell layer thinner. The secretory cells ("blasenzellen", B-cells), which are the main site for synthesis of digestive enzymes, typically contain a single large secretory vesicle. The number and volume of B-cells significantly increased during the cooling process. All these symptoms got remission during the temperature return process (Figure 1).

\section{Plasma Analysis}

Analysis of plasma metabolite concentrations is shown in Figure 2. Compared to the AT group, the contents of glucose (Glu) decreased to the minimum value $(50.78 \mathrm{mmol} / \mathrm{L})$ at $13^{\circ} \mathrm{C}$ for $24 \mathrm{~h}$. After temperature rose back to $28^{\circ} \mathrm{C}$, it recovered to the level nearly of AT $\left(\mathrm{r} 28^{\circ} \mathrm{C}=62.82 \mathrm{mmol} / \mathrm{L}\right.$, $\mathrm{AT}=64.81 \mathrm{mmol} / \mathrm{L})$ (Figure $2 \mathrm{~A})$. The contents of triglyceride (TG) and total cholesterol (TC) decreased after cooling and reached the lowest $(\mathrm{TG}=0.25 \mathrm{mmol} / \mathrm{L}, \mathrm{TC}=0.39 \mathrm{mmol} / \mathrm{L}$ ) at $23^{\circ} \mathrm{C}$, and then increased gradually and reached the peak of $0.49 \mathrm{mmol} / \mathrm{L}$ and $1.12 \mathrm{mmol} / \mathrm{L}$, respectively, in $13^{\circ} \mathrm{C}$ for $24 \mathrm{~h}$ (Figure 2B), while the change of TG contents was not statistically different with the AT group. Changes of total protein (TP) content during the cooling process were similar to the TC and TG. During the return process, the content

TABLE 1 | The real-time PCR primers used in this study.

\begin{tabular}{|c|c|c|}
\hline Primer names & Nucleotide sequences $\left(5^{\prime}-3^{\prime}\right)$ & Protein ID \\
\hline LvGRP78-F & TCATTGCCAACGACCAGGGT & AFQ62791.1 \\
\hline LvGRP78-R & TCCGATGAGACGCTTGGCAT & \\
\hline LvPERK-F & TCCTGACATCATCATTATCATCTCC & XP_027239142.1 \\
\hline LVPERK-R & TGAAGCTCATGCTCTCTGCCAATCC & \\
\hline LvelF2 $\alpha-F$ & GGAACCTGTCGTTGTCATCAGAGTAG & AGI97278.1 \\
\hline LvelF2 $\alpha-\mathrm{R}$ & AGAAGCTCTCCAACATGCCGAATG & \\
\hline LVATF4-F & GCCACGATTCAAGATGCTGC & AGI97279.1 \\
\hline LvATF4-R & TCCTCCTCGTCCATGCCATA & \\
\hline LvATF6-F & CTGTTGGGACAAGGACCATAAGC & AYM00394.1 \\
\hline LVATF6-R & GAATTGTAGGTGTGGCAGCTGTTA & \\
\hline LVIRE1-F & TGGTGAGAAGCAGCTTGTGTTGG & AFQ62792.1 \\
\hline LVIRE1-R & ACTGTTGATGAAGAGCCACTTGTAGC & \\
\hline LVXBP1-F & GTGGATCAGCAGTATCCCAACC & AFQ62793.1 \\
\hline LVXBP1-R & TGCCAAGGCAGCTGTATTGA & \\
\hline LvCasp3-F & ACATTTCTGGGCGGAACACC & AGL61582.1 \\
\hline LvCasp3-R & GTGACACCCGTGCTTGTACA & \\
\hline LVASK1-F & GCTGTGTTGAAGTCCGAGGAGAAG & AKI88007.1 \\
\hline LVASK1-R & AGCCAAGCAACCAACTCCATATCG & \\
\hline LvActin-F & GACTACCTGATGAAGATCC & AAG16253.1 \\
\hline LvActin-R & TCGTTGCCGATGGTGATCA & \\
\hline
\end{tabular}



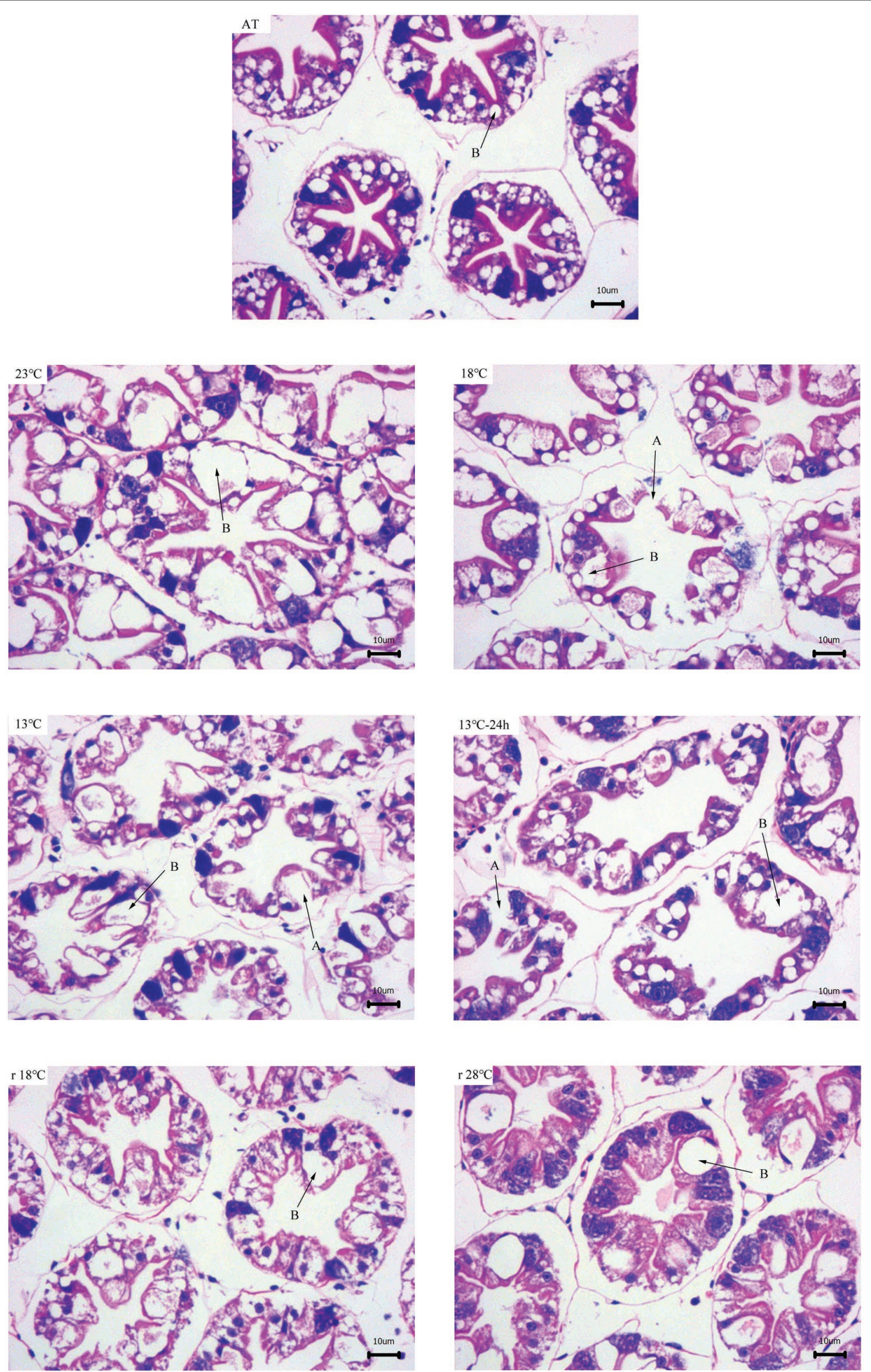

FIGURE 1 | Hepatopancreas tissue structure ( $\times 400)$ of $L$. vannamei with $\mathrm{HE}$ dying during temperature fluctuation. AT represents acclimation temperature $\left(28^{\circ} \mathrm{C}\right)$, and $r 18$ and $r 28^{\circ} \mathrm{C}$ represent 18 and $28^{\circ} \mathrm{C}$ in temperature return process, respectively. The letters in the figure indicate: A, ruptured cells; B, B-cell. 


\section{Plasma}

A

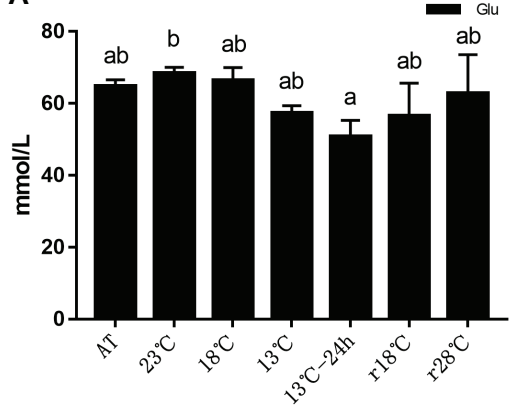

C

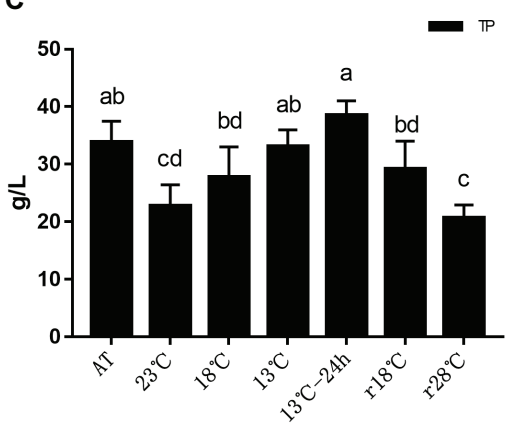

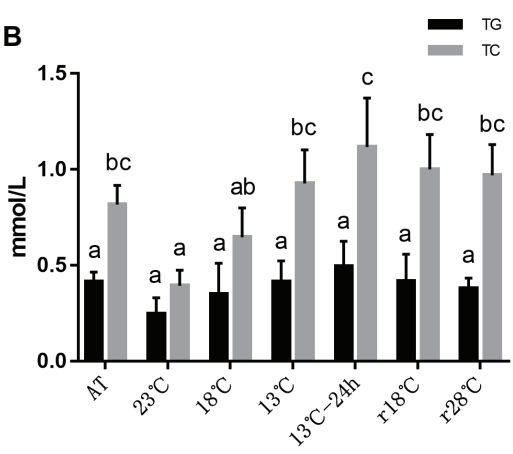

D

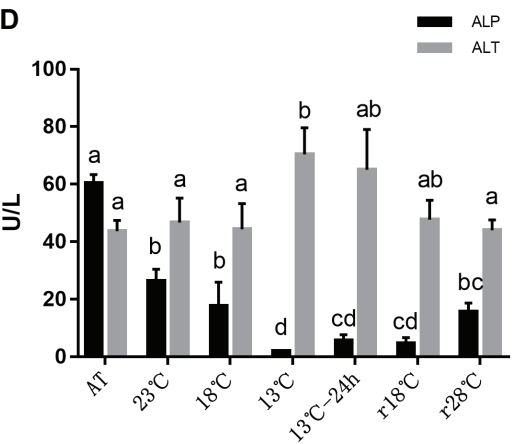

FIGURE 2 | Contents of glucose (Glu, A), triglyceride (TG) and total cholesterol (TC) (B), total protein (TP, C) and alkaline phosphatase (ALP) and alanine aminotransferase (ALT) (D) activities in plasma of $L$. vannamei during temperature fluctuation. AT represents acclimation temperature $\left(28^{\circ} \mathrm{C}\right), r 18$ and $r 28^{\circ} \mathrm{C}$ represent 18 and $28^{\circ} \mathrm{C}$ in temperature return process, respectively. The bars represent the mean \pm S.D. $(n=3)$. Statistical significance was calculated by one-way ANOVA. Bars with different letters indicate statistical differences $(p<0.05)$.

of $\mathrm{TP}$ reduced to $20.67 \mathrm{~g} / \mathrm{L}$ in $\mathrm{r} 28^{\circ} \mathrm{C}$ (Figure 2C). Alkaline phosphatase (ALP) activities in plasma decreased significantly after cooling and reached the lowest $(2 \mathrm{U} / \mathrm{L})$ at $13^{\circ} \mathrm{C}$. After temperature rose back to $28^{\circ} \mathrm{C}$, ALP activities increased to 15.67 $\mathrm{U} / \mathrm{L}$, which is near the activities at $18^{\circ} \mathrm{C}(17.67 \mathrm{U} / \mathrm{L})$ in the cooling process. Alanine aminotransferase (ALT) activities remained stable from AT to $18^{\circ} \mathrm{C}$ and then significantly increased and reached the highest level $(70.33 \mathrm{U} / \mathrm{L})$ at $13^{\circ} \mathrm{C}$. During the return process, ALT activities decreased to the level near AT (43.67 U/L) (Figure 2D).

\section{Unfolded Protein Response and Related Apoptosis Gene Expression to Temperature Fluctuation in the Hepatopancreas}

In the hepatopancreas, the relative expressions of GRP78 increased significantly at $18^{\circ} \mathrm{C}$ and reached the peak at $13^{\circ} \mathrm{C}$, which is about fourfold that at AT. During the next $24 \mathrm{~h}$ maintaining in $13^{\circ} \mathrm{C}$ and the return process, GRP78 expressions significantly decreased and they were near to the level of AT in $\mathrm{r} 28^{\circ} \mathrm{C}$ (Figure 3A). Expressions of apoptosis related genes including CASP3 and ASK1 showed the same trend with the PERK sub-pathway and their highest expression levels appeared in $13^{\circ} \mathrm{C}$ (Figure 3B). In UPR, expressions of ATF6 showed the same trend found in GRP78 (Figure 3C). In the IRE1 sub-pathway, expressions of IRE1 and XBP1 reached the peak at $18^{\circ} \mathrm{C}$ (Figure 3D). In the PERK sub-pathway, expressions of PERK, eIF2 $\alpha$, and ATF4 increased gradually during the cooling process, and the highest expressions (16.67, 9.74, and 6.21 folds compared with that at AT, respectively) appeared at $13^{\circ} \mathrm{C}$ and then decreased significantly. There was no obvious difference among the expressions of eIF2 $\alpha$ and ATF4 between $\mathrm{r} 28^{\circ} \mathrm{C}$ and AT (Figure 3E).

\section{Unfolded Protein Response and Related Apoptosis Gene Expression to Temperature Fluctuation in Hemocyte}

In the hemocyte, the expression level of GRP78 remained stable from AT to $13^{\circ} \mathrm{C}$ and then significantly increased in $13^{\circ} \mathrm{C}$ for $24 \mathrm{~h}$, which is more than twofold the level in AT. After temperature rose back, expressions of GRP78 were approximate to the level of AT in $\mathrm{r} 28^{\circ} \mathrm{C}$ (Figure 4A). For genes related to apoptosis, expressions of CASP3 and ASK1 showed the same trend with the PERK sub-pathway (Figure 4B). In UPR, the expressions of ATF6 decreased significantly after cooling in $23^{\circ} \mathrm{C}$ and then increased gradually and reached the highest level in $13^{\circ} \mathrm{C}$ for $24 \mathrm{~h}$ compared with the expression in AT. After temperature rose back, it returned to nearly the level of AT (Figure 4C). In the IRE1 sub-pathway, IRE1 and XBP1 showed a similar trend as ATF6 (Figure 4D). 


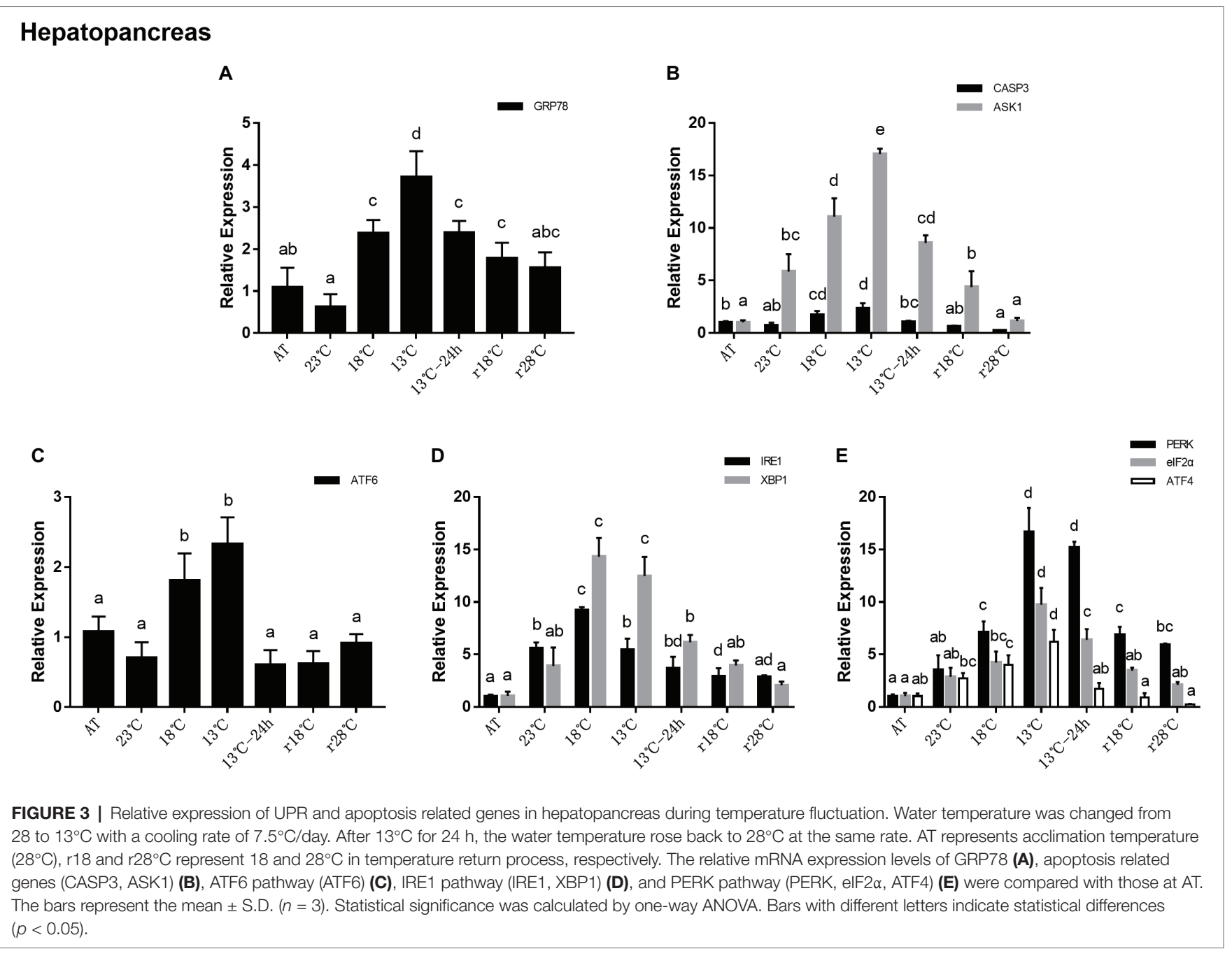

In the PERK sub-pathway, expressions of PERK, eIF2 $\alpha$, and ATF4 increased gradually after cooling, reaching at $13^{\circ} \mathrm{C}$ for $24 \mathrm{~h}$ approximately seven-, four-, and twofold, respectively, of the levels found in AT, but after temperature rose back the expressions decreased (Figure 4E).

\section{DISCUSSION}

Global climate change is impacting marine and estuarine aquaculture. It is generally known that coastal marine systems are some of the most important ecologically and socioeconomically on the planet. Temperature, as one of the interacting climatic variables, will drive future ecological changes in marine systems. Understanding how temperature change will affect the aquatic organisms is a key issue worldwide. L. vannamei, mainly distributed in the sea of Ecuador and introduced to China in 1988, is one of the most important aquaculture shrimps in the world. As its origins are tropical, temperature fluctuation is a serious challenge to its survival, growth, and distribution (Peng et al., 2015; Cottin et al., 2016).
In this study, the hepatopancreas histological changes, plasma metabolites concentrations, and relative mRNA expression in the UPR signaling pathway and apoptosis genes induced by ERS in L. vannamei during cold stress were studied.

\section{Hepatopancreas Histological Change During Temperature Fluctuation}

The hepatopancreas as a vital organ of crustaceans is involved in excretion, molting, diverse metabolic activities, and storage of energy reserves (Yepiz-Plascencia et al., 2000; Verri et al., 2001). In this study, the number and volume of B-cells in hepatopancreas tubules was significantly increased after suffering cold stress. This may be related to the fact that B-cells are the main site of absorption and digestion of nutrients (Almohanna and Nott, 1989; Wang et al., 2016). We suspected that the high rate of synthesis and release of digestive enzymes in B-cells accelerated the mobilization of nutrients in hepatopancreas tubules, by which shrimp can adapt to environmental stress.

The hepatopancreas of shrimp has high self-repairing ability. L. vannamei can repair hepatopancreas injury after long-term 


\section{Hemocyte}
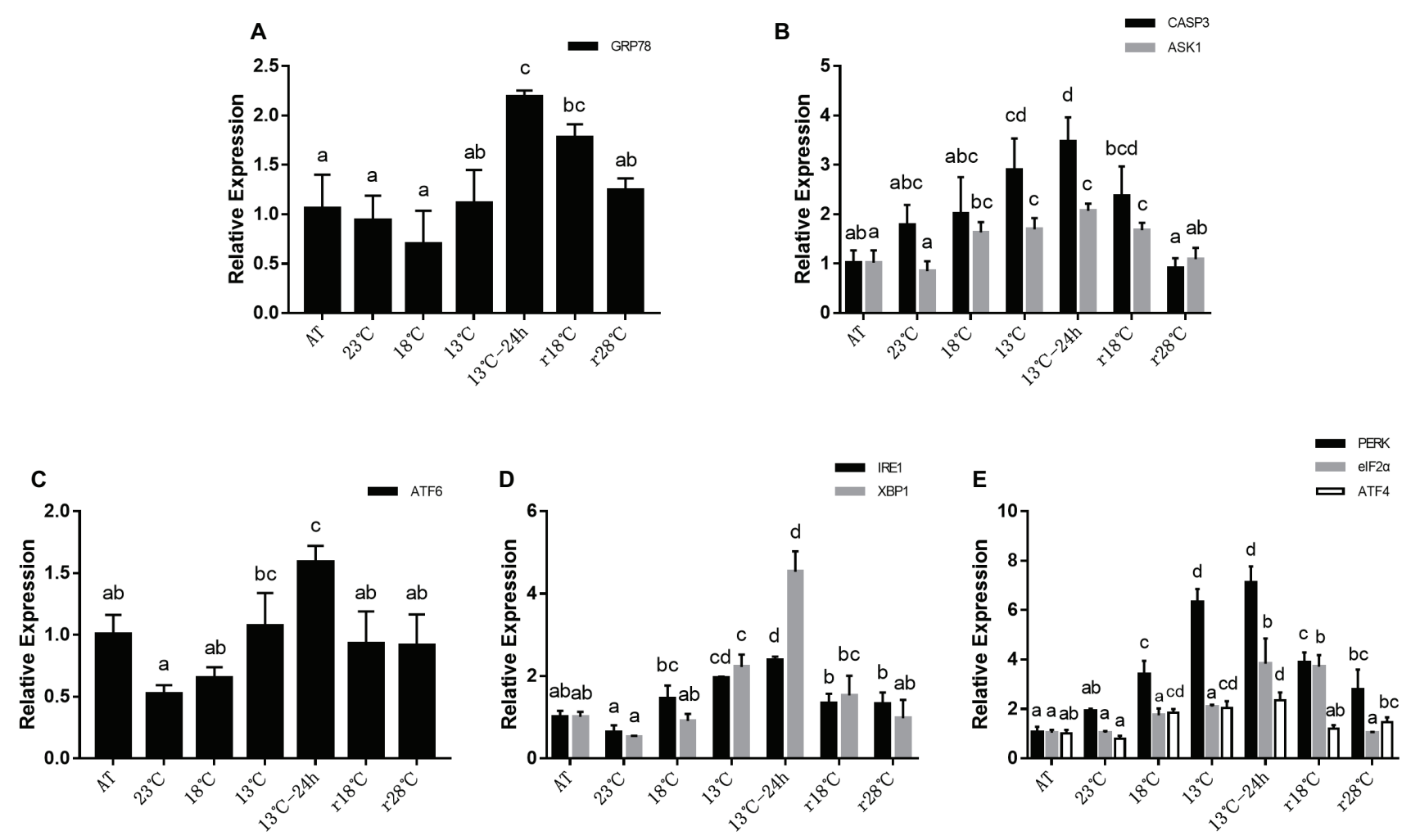

FIGURE 4 | Relative expression of UPR- and apoptosis-related genes in hemocyte during temperature fluctuation. Water temperature was changed from 28 to $13^{\circ} \mathrm{C}$ with a cooling rate of $7.5^{\circ} \mathrm{C} /$ day. After $13^{\circ} \mathrm{C}$ for $24 \mathrm{~h}$, the water temperature rose back to $28^{\circ} \mathrm{C}$ at the same rate. AT represents acclimation temperature $\left(28^{\circ} \mathrm{C}\right), \mathrm{r} 18$ and $r 28^{\circ} \mathrm{C}$ represent 18 and $28^{\circ} \mathrm{C}$ in temperature return process, respectively. The relative mRNA expression levels of GRP78 (A), apoptosis-related genes (CASP3, ASK1) (B), ATF6 pathway (ATF6) (C), IRE1 pathway (IRE1, XBP1) (D), and PERK pathway (PERK, elF2 $\alpha$, ATF4) (E) were compared with those at AT. The bars represent the mean \pm S.D. $(n=3)$. Statistical significance was calculated by one-way ANOVA. Bars with different letters indicate statistical differences $(p<0.05)$.

exposure to low zinc (Jui-Pin et al., 2008) and low $\mathrm{pH}$ (Han et al., 2018a). The hepatopancreas weight of L. vannamei significantly declined after fasting, but then increased immediately after re-feeding (Pascual et al., 2006; Sanchez-Paz et al., 2007). In the present study, histological damage of the hepatopancreas got remission after temperature return, confirming the shrimp's self-repair ability.

\section{Plasma Metabolite Concentrations Change During Temperature Fluctuation}

It has been widely accepted that protein acts as the main energy source for shrimp (New, 1976; Zhang et al., 2006; Cuzon et al., 2010). Research has shown that lipids are the main energy source of tilapia (Oreochromis niloticus) during longtime hypoxia stress (Li et al., 2018). In this study, the results showed that lipids (TC, the major components of lipids, supply and store energy) and protein (TP provides energy and transports various metabolites) in plasma responded more rapidly to temperature fluctuation, while Glu remained stable before $13^{\circ} \mathrm{C}$ and recovered to AT levels after temperature rose back to $28^{\circ} \mathrm{C}$. It has been reported that the hepatopancreas is typically high in lipids and appears to be the main site for gluconeogenesis in decapod crustaceans (Hervant et al., 1999; Vinagre and Silva, 2011; Reyes-Ramos et al., 2018; Berry et al., 2019). Thus, combined with hepatopancreas histology and plasma results, we deduced that the increase of B-cells facilitates the gluconeogenesis to synthesize glucose from protein and lipid, by which shrimps maintain glucose demand under cold stress. However, after temperature dropped to $13^{\circ} \mathrm{C}$, the rupture of hepatopancreas tubules causes lipids and proteins to enter hemolymph, resulting in an increase of lipid and protein content in plasma. The glucose content decreased at the same time due to the damage of the hepatopancreas.

It is known to all that nonspecific immunity plays an important role in the immune defense of aquatic animals. L. vannamei depends entirely on cellular and humoral immunity to prevent external injury (Iwanaga and Lee, 2005). ALP is directly involved in the transfer and metabolism of phosphoric acid groups in organisms and plays a significant role in the immune system against pathogens. The present study showed that ALP played a major role during the cold stress response in Sparus aurata and L. vannamei, and this is probably because ALP can help protect the hepatopancreas and hemolymph from cold-stress damage (Mateus et al., 2017; Peng et al., 2018). 
The activity of ALT in plasma can reflect the damage of the hepatopancreas (Jiang et al., 2014; Yan et al., 2016). It has been shown that various forms of stress can cause an increase in plasma ALT activity in fish (Cho et al., 1994), and it is responsive to temperature change in fish (Costas et al., 2012). In the present study, the ALP activity decreased to the lowest level, and the ALT activity increased to the highest level at $13^{\circ} \mathrm{C}$, indicating that the shrimp was damaged at this temperature. However, there was no obvious change in the next $24 \mathrm{~h}$ when the temperature was kept at $13^{\circ} \mathrm{C}$, but it increased significantly after the temperature rose back to $28^{\circ} \mathrm{C}$. Thus, we deduced that shrimp has the ability to adapt low-temperature stress to a certain extent, and these results were consistent with those found in the hepatopancreas histological analysis.

\section{Differential Gene Expression About Unfolded Protein Response Pathway and Apoptosis During Temperature Fluctuation}

UPR is a feedback regulatory system, capable of controlling the elimination of misfolded proteins in the ER, thereby maintaining the homeostasis of the endoplasmic reticulum. Appropriate ERS can activate UPR to improve the ER function and protect cells. But if the imbalance exceeds its regulating ability, it will lead to apoptosis. In invertebrates, apoptosis is also an effector factor of immune response. Environmental stresses such as temperature stimulation, $\mathrm{pH}$ changes, and toxic substances can induce apoptosis. In this study, the relative mRNA expressions of all UPR pathway- and apoptosis-related genes in the hepatopancreas and hemocytes were significantly changed during the cooling and re-warming process, which indicated that the UPR pathway and apoptosis participated in this process.

Previous studies indicated that shrimp can adapt to the environmental changes by self-regulation to a certain degree. In these studies, it was observed that the glutamate-oxalacetate transaminase and glutamate-pyruvate transaminase activities increased after shrimp were exposed to $\mathrm{Zn}$ for 7 days but declined after exposure for 14 and 28 days (Jui-Pin et al., 2008). Additionally, the lipid peroxidation levels in shrimp had no significant changes between 10 and 15 days after $\mathrm{Cd}$ exposure (Chiodi Boudet et al., 2015). In our study, the expressions of genes (GRP78, ATF6, IRE1, XBP1, PERK, eIF2a, and ATF4) in the hepatopancreas reached their highest level at $13^{\circ} \mathrm{C}$ instead of $13^{\circ} \mathrm{C}$ for $24 \mathrm{~h}$. The plasma metabolites concentration analysis also showed that ALT activity got its highest point at $13^{\circ} \mathrm{C}$, and the activity of ALT in plasma is inversely proportional to the health of hepatopancreas. This finding is consistent with previous studies and confirms the self-repair ability of shrimp. In addition, all these related gene

\section{REFERENCES}

Almohanna, S. Y., and Nott, J. A. (1989). Functional cytology of the hepatopancreas of Penaeus semisulcatus (Crustacea: Decapoda) during the moult cycle. Mar. Biol. 101, 535-544. doi: 10.1007/BF00541656 expressions reached their highest level in $13^{\circ} \mathrm{C}$ in hepatopancreas, while in hemocytes their peak appeared in $13^{\circ} \mathrm{C}$ for $24 \mathrm{~h}$. Thus, we deduced that the shrimp response to temperature fluctuation in the hepatopancreas may be relatively rapid compared to that that in hemolymph.

\section{CONCLUSIONS}

In this study, protein and lipid were observed to be the main energy source of $L$. vannamei during temperature fluctuation. All the three UPR pathways were involved in temperature fluctuation process, and their responses in the hepatopancreas were relatively rapid compared to that in hemolymph. All the results suggest that $L$. vannamei can adapt to a certain level of temperature fluctuation by self-regulation. However, the detailed adaptation mechanism in L. vannamei still needs further study.

\section{DATA AVAILABILITY}

All datasets generated for this study are included in the manuscript and/or the supplementary files.

\section{ETHICS STATEMENT}

This study was carried out in accordance with the recommendations of the guidelines for animal care and use for scientific research in China. The protocol was approved by the Ministry of Agriculture and Rural Affairs of the China.

\section{AUTHOR CONTRIBUTIONS}

ZW performed the study, analyzed the results, and drafted the manuscript. YQ and JL coordinated the study. MY, JZ and LF set the experimental design. All authors reviewed and approved the final manuscript.

\section{FUNDING}

This work was supported by the National Natural Science Foundation of China (31600322), National Natural Science Foundation of China (41706186), China Scholarship Council (CSC) Grant (201807630002), Guangdong Province Universities and Colleges Pearl River Scholar Funded Scheme (2018), and the program of Joint Laboratory of Guangdong Province and Hong Kong Region (201704). 
Cao, S. S., and Kaufman, R. J. (2012). Unfolded protein response. Curr. Biol. 22, R622-R626. doi: 10.1016/j.cub.2012.07.004

Chen, Y. H., and He, J. G. (2019). Effects of environmental stress on shrimp innate immunity and white spot syndrome virus infection. Fish Shellfish Immunol. 84, 744-755. doi: 10.1016/j.fsi.2018.10.069

Chen, Y. H., Zhao, L., Pang, L. R., Li, X. Y., Weng, S. P., and He, J. G. (2012). Identification and characterization of inositol-requiring enzyme-1 and X-box binding protein 1, two proteins involved in the unfolded protein response of Litopenaeus vannamei. Dev. Comp. Immunol. 38, 66-77. doi: 10.1016/j. dci.2012.04.005

Chiodi Boudet, L. N., Polizzi, P., Romero, M. B., Robles, A., Marcovecchio, J. E., and Gerpe, M. S. (2015). Histopathological and biochemical evidence of hepatopancreatic toxicity caused by cadmium in white shrimp, Palaemonetes argentinus. Ecotoxicol. Environ. Saf. 113, 231-240. doi: 10.1016/j. ecoenv.2014.11.019

Cho, C. Y., Hynes, J. D., Wood, K. R., and Yoshida, H. K. (1994). Development of high-nutrient-dense, low-pollution diets and prediction of aquaculture wastes using biological approaches. Aquaculture 124, 293-305. doi: 10.1016/0044-8486(94)90403-0

Collins, P. (2010). Environmental stress upon hepatopancreatic cells of freshwater prawns (Decapoda: Caridea) from the floodplain of Paraná River. Nat. Sci. 2, 748-759. doi: 10.4236/ns.2010.27094

Costa, C. Z. F., Rosa, S. E. A. D., and Camargo, M. M. D. (2011). The unfolded protein response: how protein folding became a restrictive aspect for innate immunity and B lymphocytes. Scand. J. Immunol. 73, 436-448. doi: 10.1111/j. 1365-3083.2010.02504.x

Costas, B., Ruiz-Jarabo, I., Vargas-Chacoff, L., Arjona, F. J., Mancera, J. M., and Dinis, M. T. (2012). Different environmental temperatures affect amino acid metabolism in the eurytherm teleost Senegalese sole (Solea senegalensis Kaup, 1858) as indicated by changes in plasma metabolites. Amino Acids 43, 327-335. doi: 10.1007/s00726-011-1082-0

Cottin, D., Shillito, B., Chertemps, T., Tanguy, A., Léger, N., and Ravaux, J. (2016). Identification of differentially expressed genes in the hydrothermal vent shrimp Rimicaris exoculata exposed to heat stress. Mar. Genomics 3, 71-78. doi: 10.1016/j.margen.2010.05.002

Cuzon, G., Cahu, C., Aldrin, J. F., Messager, J. L., Stephan, G., and Mevel, M. (2010). Starvation effect on metabolism of Penaeus japonicus. J. World Aquacult. Soc. 11, 410-423. doi: 10.1111/j.1749-7345.1980.tb00135.x

Dejean, L. M., Martinezcaballero, S., and Kinnally, K. W. (2006). Is MAC the knife that cuts cytochrome c from mitochondria during apoptosis? Cell Death Differ. 13, 1387-1395. doi: 10.1038/sj.cdd.4401949

Duan, Y., Liu, Q., Wang, Y., Zhang, J., and Xiong, D. (2018a). Impairment of the intestine barrier function in Litopenaeus vannamei exposed to ammonia and nitrite stress. Fish Shellfish Immunol. 78, 279-288. doi: 10.1016/j. fsi.2018.04.050

Duan, Y., Wang, Y., Dong, H., Li, H., Liu, Q., and Zhang, J. (2018b). Physiological and immune response in the gills of Litopenaeus vannamei exposed to acute sulfide stress. Fish Shellfish Immunol. 81, 161-167. doi: 10.1016/j. fsi.2018.07.018

Fan, L., Wang, A., Miao, Y., Liao, S., Ye, C., and Lin, Q. (2016). Comparative proteomic identification of the hepatopancreas response to cold stress in white shrimp, Litopenaeus vannamei. Aquaculture 454, 27-34. doi: 10.1016/j. aquaculture.2015.10.016

Fan, L., Wang, A., and Wu, Y. (2013). Comparative proteomic identification of the hemocyte response to cold stress in white shrimp, Litopenaeus vannamei. J. Proteome 80, 196-206. doi: 10.1016/j.jprot.2012.12.017

Han, S. Y., Wang, B. J., Liu, M., Wang, M. Q., Jiang, K. Y., and Liu, X. W. (2018a). Adaptation of the white shrimp Litopenaeus vannamei to gradual changes to a low-pH environment. Ecotoxicol. Environ. Saf. 149, 203-210. doi: 10.1016/j.ecoenv.2017.11.052

Han, S. Y., Wang, M. Q., Liu, M., Wang, B. J., Jiang, K. Y., and Wang, L. (2018b). Comparative sensitivity of the hepatopancreas and midgut in the white shrimp Litopenaeus vannamei to oxidative stress under cyclic serious/ medium hypoxia. Aquaculture 490, 44-52. doi: 10.1016/j.aquaculture.2018.02.021

He, P., Wei, P., Zhang, B., Zhao, Y., Li, Q., and Chen, X. (2018). Identification of microRNAs involved in cold adaptation of Litopenaeus vannamei by high-throughput sequencing. Gene 677, 24-31. doi: 10.1016/j.gene.2018.07.042

Hervant, F., Mathieu, J., and Culver, D. C. (1999). Comparative responses to severe hypoxia and subsequent recovery in closely related amphipod populations
(Gammarus minus) from cave and surface habitats. Hydrobiologia 392, 197-204. doi: 10.1023/A:1003511416509

Huang, W., Ren, C., Li, H., Huo, D., Wang, Y., and Jiang, X. (2017). Transcriptomic analyses on muscle tissues of Litopenaeus vannamei provide the first profile insight into the response to low temperature stress. PLoS One 12:e178604. doi: 10.1371/journal.pone.0178604

Iwanaga, S., and Lee, B. L. (2005). Recent advances in the innate immunity of invertebrate animals. J. Biochem. Mol. Biol. 38, 128-150. doi: 10.5483/ BMBRep.2005.38.2.128

Jiang, Q., Dilixiati, A., Zhang, W., Li, W., Wang, Q., and Zhao, Y. (2014). Effect of nitrite exposure on metabolic response in the freshwater prawn Macrobrachium nipponense. Cent. Eur. J. Biol. 9, 86-91. doi: 10.2478/ s11535-013-0167-4

Jui-Pin, W., Hon-Cheng, C., and Da-Ji, H. (2008). Histopathological and biochemical evidence of hepatopancreatic toxicity caused by cadmium and zinc in the white shrimp, Litopenaeus vannamei. Chemosphere 73, 1019-1026. doi: 10.1016/j.chemosphere.2008.08.019

Li, E., Chen, L., Zeng, C., Yu, N., Xiong, Z., and Chen, X. (2008). Comparison of digestive and antioxidant enzymes activities, haemolymph oxyhemocyanin contents and hepatopancreas histology of white shrimp, Litopenaeus vannamei, at various salinities. Aquaculture 274, 80-86. doi: 10.1016/j.aquaculture.2007.11.001

Li, M., Wang, X., Qi, C., Li, E., Du, Z., and Qin, J. G. (2018). Metabolic response of Nile tilapia (Oreochromis niloticus) to acute and chronic hypoxia stress. Aquaculture 495, 187-195. doi: 10.1016/j.aquaculture.2018.05.031

Madeira, D., Mendonça, V., Dias, M., Roma, J., Costa, P. M., and Larguinho, M. (2015). Physiological, cellular and biochemical thermal stress response of intertidal shrimps with different vertical distributions: Palaemon elegans and Palaemon serratus. Comp. Biochem. Physiol. A Mol. Integr. Physiol. 183, 107-115. doi: 10.1016/j.cbpa.2014.12.039

Mateus, A. P., Costa, R., Gisbert, E., Pis, P., Andree, K. B., and Estévez, A. (2017). Thermal imprinting modifies bone homeostasis in cold challenged sea bream (Sparus aurata). J. Exp. Biol. 220:156174. doi: 10.1242/jeb.156174

Mori, K. (2009). Signalling pathways in the unfolded protein response: development from yeast to mammals. J. Biochem. 146, 743-750. doi: 10.1093/jb/mvp166

Morishima, N., Nakanishi, K., Takenouchi, H., Shibata, T., and Yasuhiko, Y. (2002). An endoplasmic reticulum stress-specific caspase cascade in apoptosis. J. Biol. Chem. 277, 34287-34294. doi: 10.1074/jbc.M204973200

Nakka, V. P., Gusain, A., and Raghubir, R. (2010). Endoplasmic reticulum stress plays critical role in brain damage after cerebral ischemia/reperfusion in rats. Neurotox. Res. 17, 189-202. doi: 10.1007/s12640-009-9110-5

New, M. B. (1976). A review of dietary studies with shrimp and prawns. Aquaculture 9, 101-144. doi: 10.1016/0044-8486(76)90055-7

Pascual, C., Sánchez, A., Zenteno, E., Cuzon, G., Gabriela, G., and Brito, R. (2006). Biochemical, physiological, and immunological changes during starvation in juveniles of Litopenaeus vannamei. Aquaculture 251, 416-429. doi: 10.1016/j.aquaculture.2005.06.001

Peng, J., He, P., Wei, P., Zhang, B., Zhao, Y., and Li, Q. (2018). Proteomic responses under cold stress reveal unique cold tolerance mechanisms in the Pacific white shrimp (Litopenaeus vannamei). Front. Physiol. 9:1399. doi: 10.3389/fphys.2018.01399

Peng, J., Wei, P., Chen, X., Zeng, D., and Chen, X. (2015). Identification of cold responsive genes in Pacific white shrimp (Litopenaeus vannamei) by suppression subtractive hybridization. Gene 575, 667-674. doi: 10.1016/j. gene.2015.09.045

Reyes-Ramos, C. A., Peregrino-Uriarte, A. B., Keni, C. R., Valenzuela-Soto, E. M., Lilia, L. C., and Gloria, Y. P. (2018). Phosphoenolpyruvate carboxykinase cytosolic and mitochondrial isoforms are expressed and active during hypoxia in the white shrimp Litopenaeus vannamei. Comp. Biochem. Physiol. B: Biochem. Mol. Biol. 226, 1-9. doi: 10.1016/j.cbpb.2018.08.001

Sanchez-Paz, A., Muhlia-Almazan, A., and Yepiz-Plascencia, G. (2007). Effect of short-term starvation on hepatopancreas and plasma energy reserves of the Pacific white shrimp (Litopenaeus vannamei). J. Exp. Mar. Biol. Ecol. 340, 184-193. doi: 10.1016/j.jembe.2006.09.006

Tao, Y., Qiang, J., Hui, W., Pao, X. U., Xinyu, M. A., and Zhao, W. (2016). Acute toxicity of low-pH stress and its effect on enzyme activity and histological structure of gill and hepatopancreas in Procambarus clarkii. J. Fish. China 23, 1279-1289. doi: 10.3724/SP.J.1118.2016.16056,

Tobiume, K., Matsuzawa, A., Takahashi, T., Nishitoh, H., Morita, K., and Takeda, K. (2001). ASK1 is required for sustained activations of JNK/p38 
MAP kinases and apoptosis. EMBO Rep. 2, 222-228. doi: 10.1093/emboreports/kve046

Verri, T., Mandal, A., Zilli, L., Bossa, D., Mandal, P. K., and Ingrosso, L. (2001). D-glucose transport in decapod crustacean hepatopancreas. Comp. Biochem. Physiol. A Mol. Integr. Physiol. 130, 585-606. doi: 10.1016/ S1095-6433(01)00434-2

Vinagre, A. S., and Silva, R. S. M. D. (2011). Effects of fasting and refeeding on metabolic processes in the crab Chasmagnathus granulata (Dana, 1851). Can. J. Zool. 80, 1413-1421. doi: 10.1139/z02-122

Wang, X., Li, E., Chang, X., Qin, J. G., Wang, S., and Chen, X. (2016). Growth, body composition, ammonia tolerance and hepatopancreas histology of white shrimp Litopenaeus vannamei fed diets containing different carbohydrate sources at low salinity. Aquac. Res. 47, 1932-1943. doi: 10.1111/are.12650

Wang, P. H., Wan, D. H., Chen, Y. G., Weng, S. P., Yu, X. Q., and He, J. G. (2013). Characterization of four novel caspases from Litopenaeus vannamei (Lvcaspase2-5) and their role in WSSV infection through dsRNA-mediated gene silencing. PLoS One 8:e80418. doi: 10.1371/journal.pone.0080418

Xu, Z., Regenstein, J. M., Xie, D., Lu, W., Ren, X., and Yuan, J. (2018). The oxidative stress and antioxidant responses of Litopenaeus vannamei to low temperature and air exposure. Fish Shellfish Immunol. 72, 564-571. doi: 10.1016/j.fsi.2017.11.016

$\mathrm{Xu}$, J., Ruan, L., and Shi, H. (2014). eIF2 $\alpha$ of Litopenaeus vannamei involved in shrimp immune response to WSSV infection. Fish Shellfish Immunol. 40, 609-615. doi: 10.1016/j.fsi.2014.08.016

Yan, J., Chen, S., Chang, Q., Wang, Z., Bin, L. U., and Liu, C. (2016). Effects of antarctic krill meal replacing fish meal on growth performance, serum and liver biochemical indices and serum non-specific immune indices of juvenile spotted halibut (Verasper variegatus). Chin. J. Anim. Nutr. 28, 3503-3510. doi: 10.3969/j.issn.1006-267x.2016.11.017

Yepiz-Plascencia, G., Galván, T. G., Vargas-Albores, F., and García-Bañuelos, M. (2000). Synthesis of hemolymph high-density lipoprotein $\beta$-glucan binding protein by Penaeus vannamei Shrimp hepatopancreas. Mar. Biotechnol. 2, 485-492. doi: 10.1007/s101260000030
Yuan, Z., Chen, M., Wang, J., Li, Z., Geng, X., and Sun, J. (2018). Identification of Litopenaeus vannamei $\mathrm{BiP}$ as a novel cellular attachment protein for white spot syndrome virus by using a biotinylation based affinity chromatography method. Fish Shellfish Immunol. 79:S1717046922. doi: 10.1016/j. fsi.2018.05.003

Yuan, F. H., Chen, Y. G., Zhang, Z. Z., Yue, H. T., Bi, H. T., and Yuan, K. (2016). Down-regulation apoptosis signal-regulating kinase 1 gene reduced the Litopenaeus vannamei hemocyte apoptosis in WSSV infection. Fish Shellfish Immunol. 50, 109-116. doi: 10.1016/j.fsi.2015.12.003

Yuan, K., He, H. H., Zhang, C. Z., Li, X. Y., Weng, S. P., and He, J. G. (2017). Litopenaeus vannamei activating transcription factor 6 alpha gene involvement in ER-stress response and white spot symptom virus infection. Fish Shellfish Immunol. 70, 129-139. doi: 10.1016/j.fsi.2017.09.013

Zhang, W., Chen, B., Niu, C., Yuan, L., Jia, H., and Storey, K. B. (2019). Response of the Chinese soft-shelled turtle to acute heat stress: insights from the systematic antioxidant defense. Front. Physiol. 10:710. doi: 10.3389/ fphys.2019.00710

Zhang, P., Zhang, X., Li, J., and Huang, G. (2006). Swimming ability and physiological response to swimming fatigue in whiteleg shrimp, Litopenaeus vannamei. Comp. Biochem. Physiol., Part A: Mol. Integr. Physiol. 145, 26-32. doi: $10.1016 /$ j.cbpa.2006.04.014

Conflict of Interest Statement: The authors declare that the research was conducted in the absence of any commercial or financial relationships that could be construed as a potential conflict of interest.

Copyright (c) 2019 Wang, Qu, Yan, Li, Zou and Fan. This is an open-access article distributed under the terms of the Creative Commons Attribution License (CC BY). The use, distribution or reproduction in other forums is permitted, provided the original author(s) and the copyright owner(s) are credited and that the original publication in this journal is cited, in accordance with accepted academic practice. No use, distribution or reproduction is permitted which does not comply with these terms. 